\title{
The Tourist Bubble and the Europeanisation of Holiday Travel
}

\author{
Jens K.S. Jacobsen \\ Institute of Transport Economics, Oslo, Norway
}

This account explores certain aspects of the developments in international, interEuropean holiday travel as a part of the phenomena characterised as modernity and Europeanisation. The focus is on the idea of 'travelling parochialism', i.e. whether large proportions of contemporary international holidaymakers and other travellers on their tours within Europe adopt some kind of furtherance of a home-like culture. The main point of departure is the idea of the 'tourist bubble' understood here as a territorial and functional differentiation and as an expectation of holidaymakers going abroad. The concept of 'travel ecumene' is introduced to examine implications for travellers of the development of a western European travel system. Moreover, the study analyses the extent to which the notion of the tourist bubble is still beneficial in comprehending significant aspects of inter-European holiday travel in relation to current discourses of internationalisation, Europeanisation and cosmopolitanism. The paper also discusses advances of cosmopolitan predilections and aspirations and their possible influences on contemporary international European tourism.

Keywords: Tourist bubble; ecumene; cosmopolitanism; homogenisation; Europe

\section{Introduction}

International tourism has been described as a 'utopia of difference' (van den Abbeele, 1980: 8). In a historical perspective, international tourism within Europe has contributed to an increased knowledge of strange places and unfamiliar ways of living. At the same time, learning about contemporary foreign cultures and other peoples' lives is only of minor interest to large numbers of people crossing European national boundaries during their holidays. It appears that the realm of 'pleasure' has long been a vital mechanism for acquiring knowledge about local cultures at the destinations. Moreover, sameness in relation to pivotal facets of everyday life has been a feature of numerous holiday tours to foreign countries, not only in terms of present-day package holidays (Jacobsen, 2002), but also with regard to earlier European spa tourism (Knebel, 1960: 16-19). Generally, the principal attractions of present-day inter-European holiday travel (for instance, beaches, a warm climate, landscapes, works of art, buildings and ruins), are moderately related to otherness.

A fundamental question in the discussion of the organisation of current international pleasure travel is the extent to which tourists really experience and participate in the destination communities. Do they, for instance, primarily focus on escape from their everyday life, and do they essentially prefer to linger within some kind of elongation of their home or everyday culture? Several authors have pointed out that for multiple reasons various tourists 
abroad participate little in the communities they arrive in (Boissevain, 1996; Pearce, 1982). Still, some international holidaymakers appear to move for the most part within a prolongation of the travel-generating cultures. Such a persistent predilection for sameness seems related to the fact that numerous people still must overcome the apprehension of unfamiliar food and unusual people when they cross national boundaries during their holiday (Holloway \& Plant, 1992: 6). Several decades ago, Knebel labelled this phenomenon a 'touristic world of its own' (touristische Eigenwelt) (1960: 137). Such enclaves, quasienclaves or tourist bubbles are still a significant element of the tourism industry provisions in certain areas, even if individualisation may be an essential tendency in current inter-European pleasure travel (Bruckner \& Finkielkraut, 1979: 37-41; Knebel, 1960: 101-106; Pearce, 1982: 32).

This paper explores certain aspects of the developments in international, inter-European travel as a part of phenomena characterised as modernity and Europeanisation. The focal point here is 'travelling parochialism', i.e. whether large proportions of contemporary international holidaymakers and other travellers on their tours within Europe adopt some kind of furtherance of a home-like culture. The point of departure is the notion of the 'tourist bubble' (Smith, 1977: 6), envisaged as both a territorial and functional differentiation, as an expectation, and partly also, a necessity for various vacationers abroad. The paper discusses the extent to which the notion of the tourist bubble is still beneficial to understanding central aspects of inter-European holiday travel, in relation to current discourses of internationalisation, Europeanisation and cosmopolitanism - tendencies that, in part, contribute to (postmodern) dedifferentiation of tourism (cf. Lash \& Urry, 1994: 258-259; Rojek, 1995: 79), and thus also a reduction of the necessity of territorial separation of tourismrelated accommodations. The term 'tourist bubble' is loosely applied and used in a way slightly different to that employed by Smith (1977) and Graburn (1977). Tendencies towards cultural homogenisation of space (Castells, 1996) and their counter-reactions are sketchily incorporated here. Furthermore, the paper briefly discusses advances of cosmopolitan predilections and aspirations and their possible influences in contemporary international European tourism.

\section{Conceptual Background}

Bauman has suggested that there is a grey area with unfamiliar elements, the not-yet classified, surrounding the familiar world (1990: 147), in this case the amenities of the internationalised parts of the tourism industry and related services for holidaymakers on their brief visits abroad. Since the advances of popular pleasure travel in Europe from the middle of the nineteenth century, numerous people have pointed to the challenges surrounding holiday displacement that transcends national borders and have called for particular services from the tourism and hospitality industries to meet such challenges. Particular services for short-term visits in foreign countries are related to, for instance, payment systems, language skills (Scheuch, 1977), unambiguous food services, as well as travelogues (Dann, 1992), guidebooks, and pathfinders and interpreters in unknown territories (Cohen, 1985). It is generally difficult to avoid interpretation problems and boundary crossing in foreign travel. According to Scheuch (1977: 120-121), it was a characteristic of early 
modern tourism that organisations were developed so as to reduce the problems of change of place and to a large extent, such developments reflect the compression of tourism in time and space (Scheuch, 1972: 310).

Reducing the problems of change of place was formerly addressed mainly through territorial and functional separation (Bauman, 1990: 146-147; Scheuch, 1977: 120-123), and via the development of various complementary tourism institutions - what has been labelled 'the secondary touristic system' (Freyer, 1955; Knebel, 1960: 10). Such tendencies may also be perceived as an articulation of horizontal social differentiation; a process of division and specialisation, generally leading to autonomy of spheres and separate institutional activities (Jary \& Jary, 1991: 581; Wagner, 1994: 15). Horizontal differentiation carries the imagery of progressive separation of functions where modes of activity become more specialised and precise with the advent of modernity (Giddens, 1991: 18).

Many people who need to cross into territories where they are bound to initiate and to encounter hermeneutic problems, actively seek the services of functional mediators and enclaves marked for visitors' utilisation (Bauman, 1990: 146-147). This is commonly the situation in areas with few tourists, poorly developed facilities, language barriers and extensive cultural disparities between hosts and guests. Arguably it is particularly in the accommodation sector where contemporary European pleasure travellers experience territorial and functional differentiations of tourism services via, for instance, international style hotels, multiethnic or 'global' restaurants, and various kinds of particular home-like tourism services or enclaves.

In generating the tourist bubble, there seems to be dissimilarity between what is related to the tourists' mind-sets and what is mainly an outcome of 'the tourism industry'. Even if the tourist bubble is understood in various ways, in most cases this notion presupposes some kind of territorial separation and home-like travel institutions premeditated to evade or soften the culture shocks or experiences of otherness to which international travel and holiday displacement may lead. It was, for instance, typical of the early English tourists in the Swiss Alps to insist that the destinations and their services were modified to the visitors' expectations. A wide range of concepts of tourism enclaves, 'bubbles', and similar phenomena has been presented by Hanefors (1994: 2). To depict such aspects of travel, Cohen has employed the expression 'environmental bubble' (1972: 166), Smith described this as a 'tourist bubble' (1977: 6), while Farrell has labelled it an 'enclave of familiarity' (1979). Judd (1999: 39), discussing urban tourism developments in North America and drawing on Smith (1980), has compared the tourist bubble with a theme park that provides 'entertainment and excitement, with reassuringly clean and attractive surroundings'. Theroux has suggested that many people go abroad to experience 'home plus' something else (1986: 133), and Graburn has utilised the expression 'home-grown "bubble" of their lifestyle' (1977: 31).

Smith has defined the tourist bubble as being physically 'in' a foreign culture while socially 'outside' the culture (1977: 6). This understanding of the 'bubble' includes tourists, who congregate with their compatriots in hotel bars and lobbies, creating their own reality, as Smith has put it (1977: 6). This is not only emblematic to parts of organised group tours and resort holidays. It 
also seems to fit as a depiction of numerous young backpackers, who travel individually but follow certain trails and meet and hang out with like-minded youth at certain spots en route. In a strict sense, most travellers may be seen as being physically 'in' a foreign culture while socially 'outside' the culture, when culture is understood as place-bound or area-specific. But cultures also surpass national and regional borders (Rojek \& Urry, 1997). Moreover, local culture is regularly a fusion of many influences, also from the outside world (Hobsbawn \& Ranger, 1984).

A shortcoming with the employment of the notion of the tourist bubble in contemporary Europe is that it does not seem to be effectively attuned to discourses of internationalisation, Europeanisation and cosmopolitanism, when territorial, and partly also, functional differentiation of tourism facilities are less prevailing. Even if some holiday travel modes embody a high degree of sameness, they are not necessarily connected to particular interests in meeting compatriots and making use of territorially detached and distinctly homelike facilities.

Internationalisation is a popular and blurred perspective that refers to institutions and phenomena, which exceed nation-state frontiers. It is also related to the intensification of consciousness of the world as a whole (Robertson, 1992: 8). Furthermore, internationalisation is partially described as a tendency towards cultural homogenisation of time and space. This idea goes back to McLuhan's concept of the 'global village' (1964). Internationalisation is also seen as a consequence of the advances of 'networks of networks' (Hannerz, 1992a) and networks between places (Castells, 1996). Internationalisation may also, to some extent, be described as acculturation, whereby host communities that adapt to tourism become more like the tourists' cultures (Nuñez, 1989: 266). As Lanfant has argued '[...] tourism indirectly causes the different national societies to become gradually interlinked in economic, social and cultural networks [...]' (1980: 22). Additionally, both internationalisation and Europeanisation may be understood in relation to transnationalism (Gille \& Riain, 2002: 275), i.e. various types of border-crossings by people, texts, discourses, and so on. Frequently, Europeanisation is regarded as an orchestration of diverse and international relations rather than unidirectionality and homogenisation (Ludvigsen, 2001). Moreover, Europeanisation may be seen as the reorganisation of territory. Europeanisation is here conceived of as internationalisation processes within or emerging from Europe, including propensities towards a practical unification of Europe and other parts of the globe with many European visitors and/or considerable European influence. In a tourism research context, Europeanisation encompasses facets of de-differentiation and disembedding of tourism-associated services, predominantly related to interlinkages between the parts of civil society. Cosmopolitanism has been seen as a willingness to engage with the 'other' entailing a profound involvement with contrasting cultures, to some degree, on their own terms (Hannerz, 1990). However, what such readiness might imply seems debatable. Broadly speaking, cosmopolitans may be described as people on the move, familiar with numerous countries and cultures.

Smoothing the practical aspects of contemporary international European travel is, to a certain extent, linked to the concept of ecumene, a term borrowed 
from religion and introduced into social science by Kroeber (1945) and Hewes (1965). Ecumene is basically described as '[...] a set of functionally interconnected civilisations, linked by actual roads, sea-routes and other channels of transport and communication' (Hewes, 1965), though ecumenisation is also found in areas other than travel and communication (Berque, 1993: 32-43; Hannerz, 1992b: 39, 217-267). In recent years, the advances of the ecumene, including the development of abstract expert systems of modernity, seem to assist in easing the flows between different nations and in reducing the fear of travel to foreign cultures. This appears to be especially significant within western Europe, an area currently characterised by fairly uncomplicated and customary individual leisure travel.

To briefly summarise, Europeanisation and internationalisation in relation to this travel context includes two antagonistic forces; one is the ecumenisation with its forces of homogenity and interdependence, the other being regionalism and similar forces cultivating differences within a part of the world that is increasingly standardised on a practical level. Both these tendencies give the impression of being generally appropriate to comprehend the advances of international inter-European tourism.

\section{Home-like Holidays and Elongation of Domestic Culture}

For a more thorough understanding of the utilisation and analytic potential of the concepts 'tourist bubble' and 'tourism enclave', it is useful to take a brief glance at the current understandings of tourists themselves. A central question here is whether popular images of the holidaymakers' interests in the familiar and home-like (sameness) correspond with what people actually do when they travel abroad. It has been maintained that many holidaymakers in foreign countries are 'out of time and space' (Wagner, 1977), on several levels. Representations in the popular media are repeatedly of leisure travellers who engage in inclusive tour packages or organised resort-based trips to foreign countries and who frequently make mistakes, have a scant understanding of the societies they visit, and who are somewhat removed from local cultures (Boorstin, 1992; Turner \& Ash, 1975). However, actual differences in the activities and behaviour of package tourists and non-packaged tourists are often blurred (Jacobsen, 2000: 294).

A term such as the 'traditional tourist role' - meaning a 'type' of holidaymaker abroad - seems at least partly related to norms of non-involvement, suggesting that it is acceptable not to take interest in, or become involved in, local cultures (Knebel, 1960: 99-106). It is essential here to keep in mind that on the whole, Europeans who go abroad during their summer holidays are not explorers in foreign cultures, and the primary purpose of most vacation displacements is not to make 'discoveries' in unknown territories. This seems characteristic of numerous foreign holidaymakers in European resorts (Jacobsen, 2002) and also to various urban tourists concentrating on, for instance, shopping and entertainment. Many vacationers travelling from one European country to another should instead be compared with those who go to their summer cottages or second homes within the nation, habitually living a relaxed (family) life for a few weeks. Most Europeans go abroad as couples, families and circles of friends, which implies that they unavoidably bring with 
them parts of their everyday horizon into novel and temporary holiday environs. At least, the internal life of couples, families, or other travel parties is habitually an essential aspect of peoples' tours, and holiday displacements could thus, to some extent, be seen as a furtherance of one's everyday cultural realm. Large numbers of holidaymakers arriving at the same time in some places also make it more difficult to relate to local people and local cultures.

Cross-cultural excursions, with an intense emphasis on sameness and the upholding of central parts of one's own everyday life, may be labelled 'accidental tourism' (Tyler, 1985), localism, or anti-cosmopolitanism (Hannerz, 1990: 237-243; Merton, 1957: 387). A good number of vacationers seem not to want too much flexibility in relation to the foreign and thus focus on predictable and safe environments (Ryan, 1997: 38), while at the same time considering moderate otherness as adding flavour to their holiday. This attitude seems primarily to be expressed through an unpretentious change of scene and an unassuming preoccupation with unfamiliar and untried food (Jacobsen \& Haukeland, 2002). For instance, an increasing number of tourists who buy package tours do not seem to be particularly interested in institutional attempts to mediate and interpret local cultures through for instance tour operators' resort staff, travel guides and hospitality services dominated by an almost uniform, international style. Rather, the staffs of tour operators or travel agencies, speaking the visitors' native languages, are often perceived as a safety net, to be used in the event extraordinary problems may arise. These developments are to a large extent a consequence of improved language skills of both hosts and guests and the expansion of English as the lingua franca of inter-European travel, but they also seem to be the result of a gradual internationalisation and homogenisation of services and lifestyles.

Truly rigid attitudes towards the foreign appear to be present only amongst a minority of inter-European holidaymakers and are perhaps focussed on specific home-destination relations such as for instance, from northern Europe to the Mediterranean coastal regions. More often, a few elements of territorial and functional differentiation are preferred in relation to tourism amenities, such as English pubs in Spain or Italian restaurants in Greece. This may indicate that the weakening of the tourist bubble could be a result of changes at the destinations, just as much as alterations in the holidaymakers' attitudes. Internationalisation of tourism accommodation and other travel-related facilities generally makes it easier to be a self-determining tourist, specifically within the contexts of package tours and charter flights. At this point, however, there are apparently considerable dissimilarities between various tourists, depending on, for instance, their backgrounds in relation to dimensions such as social class, comprehension of foreign languages and country of residence.

\section{Complicated Abstract Systems Ease Travel}

Jafari has made an interesting distinction between tourist-oriented products and resident-oriented products, and has pointed out that tourist-oriented products are often created especially for the visitors (1989: 440), generally implying degrees of sameness and acculturation, that cultures which come into contact of any duration become somewhat like each other in a process of 
reciprocal borrowing (Nuñez, 1989: 265-266). But in numerous present-day tourism destination areas in Europe, the boundaries between these types of products appear to be less significant, perhaps especially in multicultural localities. Many tourists now make an effort to visit restaurants and bars where the locals go, while local residents repeatedly behave like tourists in their use of the hospitality industries within their home region. Tourism thus appears to become less notably demarcated from other types of social action, partly because many people also act as tourists within their everyday domain (Lash \& Urry, 1994: 258-259). Then again, internationalisation connected to cultural and institutional changes appears to be making European states increasingly interdependent and more alike in certain aspects.

There are several reasons (relating to the momentum of modernity) behind the development of those abstract expert systems now recognised as essential to the advances of international European tourism. While modern monetary and communication systems are extremely complex in themselves, they generally make the practicalities of tourism less complicated, in much the same way as trust in the context of border-crossing activities is also related to a reduction of complexity (Luhmann, 1979: 24-31). A salient illustration of this tendency is the growth - especially during the 1990s - in the number of automatic cash point (teller) machines with multilingual user instructions that are at the tourists' disposal even in the most remote parts of Europe. The introduction of the multinational currency, the Euro, in 2002 is another example of a system now in place to assists the tourists.

Increasing international standardisation of practical payment and other travel situations seems partly to be a consequence of the growth of multinational corporations and what has been called globalisation proper. But it also results from a more general condition of internationalisation and Europeanisation especially in the finance, travel and transport industries (for instance, airline booking systems and car rental agencies). It is obvious that multinational corporations and international business networks take an essential part in international tourism. Even in numerous remote places with few tourism facilities, major payment cards are regularly accepted in local businesses. International standardisation is reflected in restaurant menus, telephone procedures, electronic post, the world wide web and road traffic systems. In areas with many foreign visitors, most restaurants have a multilingual carte $d u$ jour and, to a large extent, they also have a number of internationally standardised items on the menu. In extreme cases, restaurants and snack bars use photographs of the items on the menu, nearly eliminating the need for verbal communication. A further example is that increasing numbers of tourists and tour guides bring their mobile telephones with them abroad, simplifying communication with the outside world both at home and in the destination areas and importantly, allowing them to make accommodation reservations and to arrange transportation en route.

The advances of internationally standardised commodities and homogenised services within Europe are not only essential to tourists (and business travellers) but are also promoted by the tourism and hospitality industries, as are interdependent systems of communications. The understanding of such changes may be seen in connection with the expansion of European and other 
international business systems and structures and those related to travel are here labelled the ecumene. Essentially, convenient international payment and communication systems, tour operators, travel agencies, air carriers, car rental agencies and multinational hotel chains, all work toward reducing the contact between inter-European travellers and foreign peoples and cultures. Subsequently, foreign travellers within Europe for the most part do not have to conform to an unfamiliar everyday life context, even without preceding territorially and functionally differentiated tourism services en route and at their destinations.

\section{Cosmopolitanism and Glocalisation - The Local in the Global}

One might assume that the internationalisation of the service sector, among hotel groups, airlines, banking conglomerates and the like, acts to eliminate differences between places. In some cases this may be the situation, such as in numerous urban and suburban centres, with their chain stores and standardised eating-places. However, the local generally does not cease to exist in the wider perspective of the European. By and large, the international, or the European, is often perceived as interconnectedness and linkages between more or less local cultures (Hannerz, 1996: 17-29).

Despite unmistakable tendencies towards practical unification, Europe is far from being a homogenised entity. This is clearly demonstrated by the fact that the peoples of Europe spoke 67 languages at the end of the twentieth century, not counting dialects (Borneman \& Fowler, 1997). Tendencies towards cultural homogenisation partly convey differentiation and resurgence of identity through language. For instance, the European Union exhibits a continual struggle between a policy that bestows equal status on multiple official languages and a policy that selects one language for sole official use, and this exertion creates a variety of practices in different contexts (Pool, 1996: 161). Even if some European languages were about to disappear at the end of the twentieth century, there has also been an increased interest in minor languages, like Gaelic (Macdonald, 1997: 56-63) and Welsh (Grin \& Vaillancourt, 1999: 49). The linguistic differentiation apparently continues within Europe, even if some languages are declining and peoples' familiarity with English is on the rise. Among western Europeans in the early 1990s, the repertoire of more than three out of four multilingual speakers included English (de Swaan, 1995: 3; referred from Borneman \& Fowler, 1997), even though English is still not extensively understood in numerous regions of contemporary Europe and by large segments of holidaymakers who go abroad. To give an example, only half of the foreign motorists in northern Norway in the summer of 1997 had a comprehensive understanding of English (Jacobsen \& Haukeland, 1998: 21).

The notion of 'glocalisation' implies that the global or the international (European) acquire local expressions (Robertson, 1995: 35-37). Consequently, the contrasts between the local and the European/quasi-global increasingly appear to be an inherent part of modern life. For instance, children are brought up with a great deal of information about other countries, and are aware of both the contrasts and similarities among them (Cullingford, 1995: 126). Europeanisation may thus be understood as an ambiguous process that promotes not only cultural unification and homogenisation of space, but also as a pro- 
cess that represents a strengthening of diversity and fragmentation. According to Smith, "[...] the idea of a "global culture" is a practical impossibility, except in interplanetary terms' (1990: 171). Smith has further argued that even tendencies towards a more or less global culture will be eclectic - like their western or European progenitors (1990: 176). Moreover, Lash and Urry suggest that increased internationalisation often entails augmented sensitivity to local features (1994: 211). A similar argument is found in the works of Massey, who points out that the global is a part of what constitutes the local (1994: 5). Determining what is local is commonly a matter of scale. If, for example, one takes a closer look at what is perceived as European, then regional diversity appears as the most typical to this part of the world.

It is regularly maintained that a crucial aspect of modernity is that social relations are disembedded ('lifted out') from local contexts of action, with a consequent interpenetration of the local and the global/European (Giddens, 1991: 22, 209). Generally, disembedding involves disengagement of social relations and exchange of information from local involvements and their recombination across larger spans of time and space. As Giddens upholds, there are two types of disembedding mechanisms that concur with advances of modern institutions: One mechanism is that of symbolic tokens; the other consists of expert systems (Giddens, 1990: 22). Symbolic tokens are here understood as a media of interchange, which can be 'passed around' without concern to particular characteristics of individuals or groups that handle them at any specific juncture (Giddens, 1990: 22). Money is one essential such token, others are, for instance, power and language. However, symbolic tokens are often national and class-specific, and power and language are seemingly less disembedded than money. In this context of international travel, disembedding predominantly entails a dependency on the professional experts in tourism, transportation and accommodation, as well as communication. Expert systems related to technical and logistical aspects of transportation, such as air travel, are well known. Also numerous local hotels and eating-places frequented by tourists are inserted into internationalised cultural and information settings. The production of tourist guidebooks is another example of disembedding of previously local knowledge and guidebook authors and publishers may be seen as constituting an expert system. Guidebooks themselves are also symbols within a tourism ecumene and tourists may be judged by the types of guidebooks they bring with them (Selänniemi, 1999: 91-92). The ever-increasing range of travel guidebooks thus contributes additionally to ecumenisation and facilitates the probability of more independent travel.

A recognised dimension of touristic behaviour is the assembly of power assets that regularly imply strategies with which to build cultural capital (Bourdieu, 1984), i.e. wealth in the form of knowledge or ideas, which legitimate the continuation of status and superiority. Related to a discourse of symbolic power, Hannerz (1990) has claimed that tourists with cosmopolitan attitudes appear to possess decontextualised cultural capital and that their aesthetic and cultural travel interests are transnational in scope, but examples are hard to find and would seem to be restricted to international 'jet-setters' and mobile middle-class professionals. Thompson and Tambyah argue that cosmopolitan ideology '[...] privileges mobility and the possession of abstract 
and contextually adaptable intellectual skills and knowledge' (1999: 237). Conversely, cultural capital seems rarely to be fully decontextualised and cosmopolitanism appears mainly to be related to more or less internationalised lifestyles within segments of populations.

An effect of internationalisation and homogenisation processes of space and travel on a practical level - here labelled ecumenisation - is that many interEuropean border-crossing tourists actively search for differentiation and otherness; wanting to find the unique areas where the process of space homogenisation does not dominate as yet. Subsequently, tourists with cosmopolitan attitudes regularly pursue the local. In present-day tourism in Europe, the ideal of the local may well occupy somewhat the same kind of canonised position as that authenticity conferred (Thompson \& Tambyah, 1999: 238) in 'the first age of modernity' (Beck, 2000: 79). Thompson and Tambyah further argue that the local becomes quasi-sacralised, '[...] on which meanings of depth, communal tradition and expressions of genuine cultural difference are projected' (1999: 238). Additionally, Thompson and Tambyah claim that there can be no resonant cosmopolitan ideology without an accompanying idealisation of local cultures as both protean and enigmatic (1999: 238). This idealisation seems significant in the current social construction of tourism spaces in Europe. Along some similar lines of thought, Robertson (1992: 173) has argued that international tourism is one of the most conspicuous locations for the contemporary production of the local and different, as well as an ongoing production of the universal. Robertson further maintains that global capitalism both promotes, and is conditioned by, cultural homogeneity and cultural heterogeneity (1992: 173). Within contemporary Europe, national and regional cultures often thrive at the same time as nations and regions become more alike and better connected on a practical level. Several European regions that are visited by quite large numbers of tourists may be seen as integrated parts of a quasiglobal or a European travel ecumene, having up-to-date amenities and infrastructures. Simultaneously, various regions are perceived as different or outstanding in relation to discernible parts of local cultures, landscapes and townscapes. Some people go primarily to 'see the sights', i.e. to obtain immediate visual impressions of renowned sites such as the Eiffel Tower in Paris without any particular interest in local culture. Others completely disregard the cultural expressions at destination areas. For instance, numerous current guidebooks ostensibly cater to mobile travellers, who take a great interest in outstanding landscapes, and are less interested in local culture and social otherness beyond visual impressions (Jacobsen et al., 1998).

\section{Current International Style - Quasiglobal or Quasi-European Patchwork}

Today, international or European style in a loose sense appears to be far more indispensable in inter-European tourism than any wish to stay strictly within an elongation of home culture. However, international style within European tourism is not what it used to be in numerous instances - a discrete modernist style in the design of buildings, interiors and menus. Current alterations intended to cater to the modern-day international tourist frequently entails hybridisation and are evolving like ethnic collages or patchworks (cf. 
Smith, 1990: 176). Quite a few of the recent manifestations of the internationalisation of tourism and travel institutions and enterprises appear to be conscious and apparently postmodern mixtures.

Various restaurant menus in both resorts and urban centres may be perceived as representations of more or less the same phenomenon as world music, and could possibly be called 'world food' or 'Euro food'. In many instances, this is neither sameness nor otherness but rather acculturation the destination communities' facilitation to tourists' desires. Scores of foreign holidaymakers who do not actively search for local style often prefer, or are satisfied with international style fare. For instance, numerous resort hotels and holiday apartment centres in the Mediterranean currently offer their clients a dish from their home country on the largely international or European style carte $d u$ jour, as the typical holidaymaker's interest in the distinctly home-like seems forsaken.

Moreover, quasiglobal or quasi-European cultural mosaics seem partly related to a prevalent search for newness and freshness, like novel dishes at restaurants and other eating-places, both in urban centres and in tourism resorts. Various types of ethnic food (Halter, 2000: 107-110) and (previously) regional cuisine (Bessière, 1998) are regularly launched to satisfy the symbolic interests of the new middle class (Munt, 1994), and some of these developments may partly be interpreted as identity shopping (Halter, 2000) and a search for meaning in the 'other' (Cohen, 1979). Contemporary omnivorousness (Peterson \& Kern, 1996) among certain tourists is seemingly also part of strategies by which to build cultural capital and convey a cosmopolitan outlook or ambition.

In an era of Europeanisation, with a ubiquitous feeling of the risk of losing local character and distinctiveness, an escalating interest in local cooking within tourism may also be seen as a counter-tendency and an endeavour to prevail and strengthen the experiences of the local. In various places in contemporary Europe, there are local initiatives to construct or reconstruct territorial identities by means of culinary heritage. Related to the same tendencies, the tourism industry also 'reinvents' food traditions (Haukeland \& Jacobsen, 2001; Warde, 1997: 63-64) and thus contributes to the dispersal of culinary specialities that formerly were confined to particular areas.

A homogenising tendency has been observed for several decades in the design of European travel institutions, like airports and business hotels. However, at numerous airports, there seems to be a change from international style and minimalism, partly towards something like populist late modernism (Harris \& Lipman, 1986). Some of the novel tourism institutions appear as a mixture of an airport, a shopping centre, a theme park and a leisure centre, in the same way as shopping centres and museums have become more like theme parks, and airports more like shopping malls. This tendency to combine, in one physical unit, elements that used to be directed towards several kinds of persons in different locations (Travis, 1987), has the effect of bolstering the notion of a cultural patchwork in various settings. 


\section{Conclusion}

It has been argued that large parts of current international leisure travel within Europe might be said to reflect a greater independence from sameness in the strictest sense - traditional, home-like, comforting and enclave-like services of the tourism and hospitality industries. Territorial and functional differentiation through distinctive elongations of travellers' home cultures appears to be relatively less significant for various reasons relating to greater numbers of 'experienced' tourists, improved language skills both among hosts and guests, and the advances of more comprehensive 'explorer' or traveller attitudes (to some extent also within charter tourism and package travel). This situation seems especially characteristic of many smaller and peripheral destinations, where a high degree of sameness and international style is frequently less significant both in overnight accommodation and in eating-places. In such instances, even proportions of those who arrive as organised tours may escape travel industry-controlled and clearly predictable vacation settings. Still, substantial sectors of contemporary inter-European pleasure travel are oriented towards a quite high level of tourism organisation; semi-secluded tourism sanctuaries and a degree of sameness within spaces that are more or less reserved for foreign visitors. In this way, the 'tourist bubble' is much in evidence, as Smith $(1977,1989)$ has pointed out. Within Europe, numerous international tourists still behave as Smith (1977: 6) has described them: they congregate with their compatriots in bars and restaurants, creating a holiday reality of their own within a foreign country. Such behaviour provides safety or familiarity in strange places, as well as a forum for exchange of the latest holiday experiences (Crompton, 1981). This often appears to be the case for group sightseeing tours, where daily excursions in unfamiliar territories are brought to a close at a home-like or international style hotel or restaurant in the evening. These same tendencies are found among holidaymakers who mingle with fellow citizens in the coastal resorts of the Mediterranean area. Sustained utilisation of 'conventional' and enclave-like tourism amenities within Europe seems to result not only from an orientation towards fellow holidaymakers from their home country, but also to find playmates for children and teenagers, frequently as an expression of collective vacation styles delimited by barriers of both language, culture and social class. The often great number of novices at several resort destinations contributes in the same direction. Furthermore, certain eating-places and bars in foreign places serve as rendezvous spots for like-minded 'individual' tourists, including young backpackers.

Some European holiday enclaves for foreign visitors represent a high degree of sameness, especially if they cater solely to visitors from a single country. The use of such enclaves appears to be typical of scores of holidaymakers from larger countries such as United Kingdom, Germany and France, while they are less representative of multilingual vacationers from smaller nations, like the Scandinavian countries and the Netherlands. What might be labelled Europeanised tourism accommodation regularly caters to a polyglot audience from numerous countries, comprising holidaymakers from smaller countries, and may chiefly be regarded as functional separation. Even if it also represents 
degrees of territorial separation it does not necessarily depict sameness in a strict sense.

As suggested here, an essential challenge regarding the concept of the tourist bubble in current international European tourism is that it is not effectively attuned to the discourses of internationalisation, Europeanisation and cosmopolitanism, and the cultural homogenisation of space. Accordingly, the bubble seems not wholly pertinent as a basic description of current accommodation in inter-European holiday tours, as both territorial and functional differentiation of tourism services have deteriorated in various instances. Perceived risks related to foreign travel in Europe ostensibly seem to have gradually changed, from an emphasis on cultural aspects, including food, to an accentuation of personal safety and financial risk (value for money). In a strict sense, most pleasure travellers with time constraints may still be seen as being physically 'in' a foreign culture but socially 'outside' the culture, when culture is understood as predominantly place-bound or area-specific.

Today, it is not only international travellers who expect hotel, restaurant and transportation personnel to be multilingual and solicitous, as Smith has pointed out (1977). Such expectations appear to be present no matter who the customers are: tourists, business travellers, local residents, or someone else thereby reducing the necessity of or meticulous interests in territorial separation or differentiation in a strict sense. Moreover, this development deceptively exerts an influence on international standardisation of services partially resulting from acculturation processes. Emergent demands for multilingual hospitality staff and 'patchwork menus' are also an outcome of frequent multicultural expansions in European cities and towns. For instance, numerous hotel and restaurant staff are familiar with languages other than those generally spoken in the locations of the service enterprises. This is also augmented by international migration of tourism and hospitality service staff.

As Robertson has maintained, global and also European capitalism both promotes and is conditioned simultaneously by cultural homogeneity and cultural heterogeneity (1992: 173). Such assumptions imply that both similar and antagonistic logics are unfolding at the same time. On the one hand, there is a continuation of territorial and functional differentiation and a considerable degree of sameness, both within tourism proper and with regard to central business and shopping districts in numerous European urban centres. On the other hand, ecumenisation and similar logics contribute to apparently interminable blurring of demarcations between tourist-oriented products and resident-oriented products. Tourism amenities and tourism-like experiences are thus increasingly becoming parts of everyday life for Europeans, and such de-differentiation may, to some degree, be interpreted as an expression of postmodernity. Moreover, such developments appear to a considerable extent to be the produce of various international networks relating to communication and business and are also an outcome of improved channels of transport and communication, functionally linking European nations and regions.

In summary, distinct and clearly differentiated travel amenities - the secondary touristic system (Knebel, 1960) - intended to reduce the problems related to change of place were apparently typical to the era of 'organised capitalism' (Offe, 1985), early modernity or 'the first age of modernity', to cite 
Beck (2000). The advances of a travel ecumene and the abstract expert systems in the current era of late modernity or 'the second age of modernity', generally ease the passage between different European nations and also contributes to a reduced fear of travel to foreign places. Standardised payment systems and the gradual diffusion of English as the lingua franca seems to increase the exchange between hosts and guests. These and analogous developments also endow the individualisation of travel and make it easier for holidaymakers in foreign countries to devote more of their travel time to aspects other than the pragmatic ones, as there is generally less of a cultural risk and fewer timeconsuming practicalities connected to activities 'outside the bubble'. Following the reasoning of Beck, a cosmopolitan perspective seems essential to further studies of international European tourism in the second age of modernity (2000: 79). Border-crossing tourists with more or less cosmopolitan attitudes regularly seek the local as a canonised or 'quasi-sacralised' aspect of their tours. This development seems, at least partly, to reflect an employment of otherness as a commodity in segments of the tourism industry. Answering such engrossments with the local appears to be increasingly important to numerous European tourism destinations, repeatedly as a reaction against homogenising tendencies and standardised travel products related to Europeanisation, ecumenisation and other processes of internationalisation.

\section{Correspondence}

Any correspondence should be directed to Jens Kr. Steen Jacobsen, Institute of Transport Economics, PO Box 6110 Etterstad, NO-0602 Oslo, Norway (jsj@toi.no).

\section{References}

Bauman, Z. (1990) Modernity and ambivalence. In M. Featherstone (ed.) Global Culture (pp. 143-169). London: Sage.

Beck, U. (2000) The cosmopolitan perspective: Sociology of the second age of modernity. British Journal of Sociology 51 (1), 79-105.

Berque, A. (1993) L'ecumene: Per una problematica ambientale del mondo. Spazio e Societa (Space \& Society) 16 (Oct-Dec), 32-43.

Bessière, J. (1998) Local development and heritage: Traditional food and cuisine as tourist attractions in rural areas. Sociologia Ruralis 38 (1), 21-34.

Boissevain, J. (1996) Ritual, tourism and cultural commoditization in Malta: Culture by the pound? In T. Selwyn (ed.) The Tourist Image (pp. 105-120). Chichester: John Wiley \& Sons.

Boorstin, D.J. (1992) [1961] The Image. New York: Vintage.

Borneman, J. and Fowler, N. (1997) Europeanization. Annual Review of Anthropology 26, 487-514.

Bourdieu, P. (1984) Distinction. London: Routledge \& Kegan Paul.

Bruckner, P. and Finkielkraut, A. (1979) Au coin de la rue, l'aventure. Paris: Éditions du Seuil.

Castells, M. (1996) The Information Age, vol. 1: The Rise of the Network Society. Oxford: Blackwell.

Cohen, E. (1972) Toward a sociology of international tourism. Social Research 39 (1), 164-182.

Cohen, E. (1979) A phenomenology of tourist experiences. Sociology 13, 179-201.

Cohen, E. (1985) The tourist guide: The origins, structure and dynamics of a role. Annals of Tourism Research 12, 5-29. 
Crompton, J.L. (1981) Dimensions of the social group in pleasure vacations. Annals of Tourism Research 8, 550-568.

Cullingford, C. (1995) Children's attitudes to holidays overseas. Tourism Management $16(2), 121-127$.

Dann, G.M.S. (1992) Travelogs and the management of unfamiliarity. Journal of Travel Research 30 (4), 59-63.

de Swaan, A. (1995) The Language Constellation of the European Union. Amsterdam: Amsterdam School for Social Science Research.

Farrell, B.H. (1979) Tourism's human conflicts. Annals of Tourism Research 6, 122-136.

Freyer, H. (1955) Theorie des gegenwärtigen Zeitalters. Stuttgart: Deutsche VerlagsAnstalt.

Giddens, A. (1990) The Consequences of Modernity. Cambridge: Polity.

Giddens, A. (1991) Modernity and Self-Identity. Cambridge: Polity.

Gille, Z. and Riain, S.Ó. (2002) Global ethnography. Annual Review of Sociology 28, 271-295.

Graburn, N.H.H. (1977) Tourism: The sacred journey. In V.L. Smith (ed.) Hosts and Guests: The Anthropology of Tourism (pp. 17-31). Philadelphia: University of Pennsylvania Press.

Grin, F. and Vaillancourt, F. (1999) The Cost-Effectiveness Evalutation of Minority Language Policies: Case Studies on Wales, Ireland and Basque Country. Flensburg: European Centre for Minority Issues.

Halter, M. (2000) Shopping for Identity: The Marketing of Ethnicity. New York: Schocken.

Hanefors, M. (1994) Living the South: Tourists as boundary makers and boundary markers. Paper presented at the XIIIth World Congress of Sociology, Bielefeld, Germany.

Hannerz, U. (1990) Cosmopolitans and locals in world culture. In M. Featherstone (ed.) Global Culture (pp. 237-251). London: Sage.

Hannerz, U. (1992a) The global ecumene as a network of networks. In A. Kuper (ed.) Conceptualizing Society (pp. 34-58). London: Routledge.

Hannerz, U. (1992b) Cultural Complexity: Studies in the Social Organization of Meaning. New York: Columbia University Press.

Hannerz, U. (1996) Transnational Connections: Culture, People, Places. London: Routledge.

Harris, H. and Lipman, A. (1986) Viewpoint: A culture of despair: Reflections on 'postmodern' architecture. Sociological Review 34, 837-854.

Haukeland, J.V. and Jacobsen, J.K.S. (2001) Gastronomy in the periphery. Paper presented at the 10th Nordic Tourism Research Conference, Vasa, Finland, 18-20 October.

Hewes, G.W. (1965) The ecumene as a civilizational multiplier system. Kroeber Anthropological Society Papers 25 (Fall), 73-109.

Hobsbawm, E. and Ranger, T. (eds) (1984) The Invention of Tradition. Cambridge: Cambridge University Press.

Holloway, J.C. and Plant, R.V. (1992) Marketing for Tourism (2nd edn). London: Pitman. Jacobsen, J.K.S. (2000) Anti-tourist attitudes. Annals of Tourism Research 27, 284-300.

Jacobsen, J.K.S. (2002) Southern comfort: A study of holiday style patterns of Northerners in coastal Mallorca. Scandinavian Journal of Hospitality and Tourism 2 (1), 49-78.

Jacobsen, J.K.S. and Haukeland, J.V. (1998) Utenlandsk Bilturisme $i$ det Nordlige Norge 1997 (Foreign Motor Tourism in Northern Norway 1997). Research Report 399. Oslo: Institute of Transport Economics, Norwegian Centre for Transport Research.

Jacobsen, J.K.S. and Haukeland, J.V. (2002) A lunch with a view: Motor tourists' choices and assessments of eating-places. Scandinavian Journal of Hospitality and Tourism 2 (1), 4-16.

Jacobsen, J.K.S., Heimtun, B. and Nordbakke, S.T.D. (1998) Det Nordlige Norges Image: Innholdsanalyse av Utenlandske Reisehåndbøker (The Image of Northern Norway: Content Analysis of Foreign Guidebooks). Research Report 398. Oslo: Institute of Transport Economics, Norwegian Centre for Transport Research.

Jafari, J. (1989) Structure of tourism. In S.F. Witt and L. Moutinho (eds) Tourism Market- 
ing and Management Handbook (pp. 437-442). Hemel Hempstead: Prentice Hall International.

Jary, D. and Jary, J. (1991) Collins Dictionary of Sociology. Glasgow: HarperCollins.

Judd, D.R. (1999) Constructing the tourist bubble. In D.R. Judd and S.S. Fainstein (eds) The Tourist City (pp. 35-53). New Haven: Yale University Press.

Knebel, H.-J. (1960) Soziologische Strukturwandlungen im modernen Tourismus. Stuttgart: Ferdinand Enke Verlag.

Kroeber, A.L. (1945) The ancient Oikoumene as an historic culture aggregate. Journal of the Royal Anthropological Institute 75, 9-20.

Lanfant, M.-F. (1980) Introduction: Tourism in the process of internationalization. International Social Science Journal 32 (1), 14-43.

Lash, S. and Urry, J. (1994) Economies of Signs and Space. London: Sage.

Ludvigsen, J. (2001) The International Networking between European Logistical Operators. Stockholm: Stockholm School of Economics.

Luhmann, N. (1979) Trust and Power. Chichester: John Wiley \& Sons.

Macdonald, S. (1997) Reimagining Culture: Histories, Identities and the Gaelic Renaissance. Oxford: Berg.

Massey, D. (1994) Space, Place and Gender. Cambridge: Polity.

McLuhan, M. (1964) Understanding Media. London: Routledge \& Kegan Paul.

Merton, R.K. (1957) Social Theory and Social Structure. Glencoe, IL: Free Press.

Munt, I. (1994) The 'other' postmodern tourism: Culture, travel and the new middle classes. Theory, Culture $\mathcal{E}$ Society 11: 101-123.

Nuñez, T. (1989) Touristic studies in anthropological perspective. In V.L. Smith (ed.) Hosts and Guests: The Anthropology of Tourism (2nd edn) (pp. 265-279). Philadelphia: University of Pennsylvania Press.

Offe, C. (1985) Disorganized Capitalism: Contemporary Transformations of Work and Politics. Cambridge: Polity.

Pearce, P.L. (1982) Tourists and their hosts: Some social and psychological effects of inter-cultural contact. In S. Bochner (ed.) Cultures in Contact (pp. 199-222). Oxford: Pergamon.

Peterson, R.A. and Kern, R. (1996) Changing highbrow taste: From snob to omnivore. American Sociological Review 61, 900-907.

Pool, J. (1996) Optimal language regimes for the European Union. International Journal of the Sociology of Language 121, 159-179.

Robertson, R. (1992) Globalization: Social Theory and Global Culture. London: Sage.

Robertson, R. (1995) Glocalization: Time-space and homogeneity-heterogeneity. In M. Featherstone, S. Lash and R. Robertson (eds) Global Modernities (pp. 25-44). London: Sage.

Rojek, C. (1995) Decentring Leisure. London: Sage.

Rojek, C. and Urry, J. (1997) Transformations of travel and theory. In C. Rojek and J. Urry (eds) Touring Cultures (pp.1-19). London: Routledge.

Ryan, C. (1997) Similar motivations - diverse behaviours. In C. Ryan (ed.) The Tourist Experience (pp. 25-47). London: Cassell.

Scheuch, E.K. (1972) Ferien und Tourismus als neue Formen der Freizeit. In E.K. Scheuch and R. Meyersohn (eds) Soziologie der Freizeit (pp. 304-317). Cologne: Kiepenheuer \& Witsch.

Scheuch, E.K. (1977) Soziologie der Freizeit. In R. König (ed.) Handbuch der empirischen Sozialforschung, vol 11 (pp.1-192). Stuttgart: Ferdinand Enke Verlag.

Selänniemi, T. (1999) Sakrale steder og profane turister (Sacred places and profane tourists). In J.K.S. Jacobsen and A. Viken (eds) Turisme: Stedet $i$ en Bevegelig Verden (Tourism: Place in a Moveable World) (pp. 88-95). Oslo: Scandinavian University Press.

Smith, A.D. (1990) Towards a global culture? In M. Featherstone (ed.) Global Culture (pp. 171-191). London: Sage.

Smith, D. (1980) New to Britain: A Study of some Developments in Tourist Attractions. London: English Tourist Board. 
Smith, V.L. (1977) Introduction. In V.L. Smith (ed.) Hosts and Guests: The Anthropology of Tourism (pp. 1-14). Philadelphia: University of Pennsylvania Press.

Smith, V.L. (1989) Introduction. In V.L. Smith (ed.) Hosts and Guests: The Anthropology of Tourism (2nd edn) (pp. 1-17). Philadelphia: University of Pennsylvania Press.

Theroux, P. (1986) Sunrise with Seamonsters. Harmondsworth: Penguin.

Thompson, C.J. and Tambyah, S.K. (1999) Trying to be cosmopolitan. Journal of Consumer Research 26 (3), 214-241.

Travis, A.S. (1987) Museums, theme-parks and developments in tourism. Loisir et Société 10 (1), 13-21.

Turner, L. and Ash, J. (1975) The Golden Hordes: International Tourism and the Pleasure Periphery. London: Constable.

Tyler, A. (1985) Accidental Tourist. London: Chatto \& Windus.

van den Abbeele, G. (1980) Sightseers: The tourist as theorist. Diacritics 10 (December), 3-14.

Wagner, P. (1994) A Sociology of Modernity. London: Routledge.

Wagner, U. (1977) Out of time and place - mass tourism and charter trips. Ethnos 42 (1-2), 38-52.

Warde, A. (1997) Consumption, Food and Taste. London: Sage. 